\title{
EVALUATION AND UTILIZATION OF OLIVE EXTRACTS POLYPHENOLS AS NATURAL ANTIOXIDANTS
}

\section{Khalifa, A.H.A. ${ }^{1}$; B.R. Ramadan ${ }^{1 *}$; R.A.H. El-Dengawy2; M.F.} Khalil ${ }^{3}$ and Z.S.M. Ali ${ }^{3}$

1- Food Sci. \& Tech. Dept., Fac. of Agric., Assiut Univ., Assiut, Egypt

2- Food Industries Dept., Fac. of Agric. at Damietta, Mansoura Univ., Egypt

3- Oil and Fat Tech. Dept., Agric. Res. Center, Giza, Egypt

*E-mail: bramadan1958@yahoo.com

\begin{abstract}
The objective of this study was to evaluate the polyphenol contents as affected by ripening of Kronaki, Chemlali, Frantoio and Mission olive varieties grown in the New Valley Governorate, Egypt. Besides, the effect of ripe Kronaki olive's total polyphenols addition on sunflower oil stability as natural antioxidants was evaluated. Total polyphenols content of virgin, crude pomace olive oils and vegetation water significantly increased from unripe to the ripe stage in all varieties. Kronaki fruits recorded the highest total polyphenols content followed by Frantoio, Mission and Chemlali in both two ripening stages. Total polyphenol contents were 315 and 335 ppm for virgin oil, 68 and 75 ppm for crude pomace oil and 230 and 250 ppm for vegetation water of Kronaki fruits at unripe and ripe stage, respectively. Polyphenol compounds of the studied virgin olive oils at ripe stage were determined by HPLC. $p$ coumaric acid was the predominant polyphenols compound represented 13.40 , $11.53,9.50$ and $7.70 \%$ followed by o-coumaric acid which recorded $5.98,6.54,8.78$ and $7.37 \%$ of total polyphenols in Kronaki, Mission, Frantoio and Chemlali, respectively. Moreover, gallic, catechin, $p$-hydroxybenzoic, salicylic, quercetin, cinnamic acids and phenol present as minor compounds in all studied olive oils. The stability of sunflower oil was increased with increasing the level of olive's polyphenols extract addition. Polyphenols extract addition at $0.15 \%$ exhibited remarkable antioxidant activity of sunflower oil and its stability reached to about two-folds compared with the control. Besides, the polyphenols extract from vegetation water was more effective on sunflower oil stability compared with that of virgin or crude pomace oil extracts. That encourages using the vegetation water (a by-product of olive oil industry) polyphenols extract as natural antioxidant source.
\end{abstract}

Keywords: Virgin olive oil, crude pomace oil, vegetation water, polyphenols, antioxidants.

\section{INTRODUCTION}

Olives (Olea europea L.) include many cultivars which are used for oil extraction and pickling. Olive oil extracted from olive fruits, which can be consumed in its natural state without begin further treated or refined. The oil obtained from mature fruits by mechanical means, without any chemical treatment, is called "virgin" (Aguilera et al., 2005). Olive pomace and vegetation water are by-products of virgin olive oil processing (Firestone et al., 1988). Maturity is one of the most important factors associated with the quality evaluation of olive oil. During ripening, important chemical changes occur inside the drupes which are related to the synthesis of organic substances, especially triglycerides, and other enzymatic activities (Boskou, 1996). The beneficial effects of olive oil are due to not only its high 
Khalifa, A.H.A. et al.

unsaturated/saturated fatty acid ratio, but also its antioxidants such as vitamin E, carotenoids and phenolic compounds ( Visioli andGalli, 1998 and Caruso et al., 1999) and These substances also contribute to the stability of the oil (Papadopoulos and Boskou, 1991; Montedoro et al.,1992; and Caruso et al.,1999 .The level of phenolic compounds in virgin olive oil was an important factor in evaluating its quality, as the polyphenols increase the oxidative stability of the oil increase, as well as being responsible for the pungency and bitterness of the oil (Gutiérrez-Rosales et al., 1992). Moreover, phytochemicals, like phenolic acid and flavonoids have a very strong antioxidant activity in colon and liver cancer (Liu, 2000). The antioxidant properties of phenolics are mainly because of their rodox properties which allow them to act as reducing agents, hydrogen donators and singlet oxygen quenchers (Rice-Evans et al., 1997). Polyphenols also, act as chelators of metal ions, preventing metal catalysed formation of initiating radical species (Salah et al., 1995). Phenolic fraction of virgin olive oil ranged from 50 to $1000 \mathrm{mg} / \mathrm{kg}$ as reported by Montedoro et al. (1992) and ranged from 50 to $500 \mathrm{mg} / \mathrm{kg}$ as caffeic acid as found by Akasbi et al. (1993). Salvador et al. (2001) observed that the total polyphenols increased at the last stage of maturity, while Gimeno et al. (2002) showed that phenols were decreased during ripening. On the other hand Chimi and Atouati (1994) observed that during ripening, the concentration of phenol compounds progressively increased until it reached a maximum at the "spotted" and "purple" pigmentation stage, after which it decreased. Oxidation of oils not only affect their flavor characteristics, but also influences their nutritive value (Duch et al., 1992). The stability of virgin oil to oxidation has been correlated to the total amount of phenolic components as well as to the o-diphenols and to selected simple phenol components (Papadopoulos and Boskou, 1991 and Gennaro et al., 1998). The use of synthetic compounds acts as antioxidants not effective in preventing the development of initial off-flavor. Therefore, the use of natural antioxidants is highly desirable to replace the synthetic antioxidants (Papadopoulos and Boskou, 1991 and Satue et al., 1995). However, addition of purified polyphenols extracted from olive oil inhibited the oxidative deterioration of soybean oil (Fayed et al., 1988) and improved cotton seed oil stability (Khalil, 1994) as well as reduced the oxidation of sunflower oil (Farag et al., 2004). In recent years, the use of some synthetic antioxidant has been restricted because of their possible toxic and carcinogenic effects (Frankel et al., 1995; Gazzani et al., 1998 and Yen et al., 1998). This study aims to evaluate the total polyphenols content of four olive varities as affected by two repining stages, as well as using olive's polyphenol extracts as natural antioxidants for sunflower oil stability.

\section{MATERIALS AND METHODS}

\section{Materials:}

\section{Olive fruit samples:-}

Forty $\mathrm{kg}$ fruits of four olive (Olea europea L.) varieties namely; Chemlali, Kronaki, Frantoio and Mission were obtained from El-Dakhala Oasis, New Valley Governorate, Egypt, during 2005 season. The olive fruits 
were collected at two stages of maturity, the first one was unripe stage (at September, 15) and the second was ripe stage (at November, 15).

Sunflower oil: Sunflower oil was obtained from the local market at Cairo, Egypt.

Methods:

A-Sample preparation:-

Extraction of virgin olive oil, crude pomace oil and vegetation water:

The fruits of the studied olive cultivars were cleaned, crushed by electric crusher, packed in cheesecloth and squeezed with a hydraulic laboratory presser (Craver press.). The resultant extract (oil and vegetation water) was transferred into a separatory funnel and the oil layer was separated, dried by anhydrous sodium sulfate, filterated and kept in brown bottles at $-20^{\circ} \mathrm{C}$ until analyses. The vegetation water layer was collected, bottled and stored at $-20^{\circ} \mathrm{C}$. The crude pomace oil was extracted from the olive pomace by $n$-hexan, dried and filtered after evaporation of the solvent and kept as above mentioned.

\section{B-Analytical methods:-}

Evaluation of sunflower oil: The refractive index (at $20^{\circ} \mathrm{C}$ ), iodine value, acid value and peroxide value of sunflower oil were determined according to AOAC (2000) methods.

Determination of total polyphenols:

Extraction of total polyphenols: Total polyphenols were extracted from virgin and crude pomace olive oils according to Gutifinger (1981). Five grams of oils were dissolved in $50 \mathrm{ml}$-hexan and the solution was extracted successively with three $20 \mathrm{ml}$ portion of $60 \%(\mathrm{v} / \mathrm{v})$ aqueous methanol. The mixture was shaken each time for $2 \mathrm{~min}$. the combined extracts were brought to dryness in a vacuum rotary evaporator at $40^{\circ} \mathrm{C}$. The residue was dissolved in $1 \mathrm{ml}$ methanol and stored at $-20^{\circ} \mathrm{C}$ until use.

Total polyphenols were extracted from vegetation water according to the method outlined by Capasso et al. (1992). A known volume of vegetation water $(14 \mathrm{ml})$ was extracted with ethyl acetate $(4 \times 20 \mathrm{ml})$ and then with n-butanol $(4 \times 19 \mathrm{ml})$. The combined extracts were filtered, dried in precance anhydrous $\mathrm{Na}_{2} \mathrm{SO}_{4}$ and evaporated to dryness using rotary evaporator at $40^{\circ} \mathrm{C}$. The residue was dissolved in $1 \mathrm{ml}$ methanol and stored at $-10^{\circ} \mathrm{C}$ until use.

Colorimetric determination of total polyphenols: The concentrated total polyphenols in the methanolic extract was estimated with Folin-Ciocalteau regent (Gutifinger, 1981). $0.1 \mathrm{ml}$ of the extract was diluted by distilled water to $5 \mathrm{ml}$ in a $10 \mathrm{ml}$ voltametric flask, and then Folin-Ciocalteau regent $(0.5 \mathrm{ml})$ was added. After 3 min., one $\mathrm{ml}$ of saturated $\mathrm{Na}_{2} \mathrm{SO}_{4}$ solution was added. The content was measured after $1 \mathrm{~h}$ at $725 \mathrm{~nm}$ against a reagent blank. Caffeic acid as a standard compound was used to preparation the calibration curve.

HPLC Determination of phenolic compounds:

A Hewlett-Packard HPLC (Model 1100) at Agric. Res., Center, Giza using a hypersil C18 reversed phase column $(250 \times 4.6 \mathrm{~mm})$ with $5 \mu \mathrm{m}$ particle size-injection by means of Rheodyne injection value (Model 7125) with $50 \mu \mathrm{l}$ fixed loop was used. A constant flow rate of $1 \mathrm{ml} / \mathrm{min}$. was used 
Khalifa, A.H.A. et al.

with two mobile phases (A) $0.5 \%$ acetic acid in distilled water at $\mathrm{pH} 2.65$ and solvent (B) $0.5 \%$ acetic acid in $99.5 \%$ acetonitrile. The elution gradient was linear starting with (A) and ending with (B) over 35 min, using a UV detector set at wavelength $245 \mathrm{~nm}$. Phenolic compounds of each sample were identified by comparing their relative retention times with those of the standards mixture chromatography. The concentration of an individual compounds was calculated based on peak area measurements, then converted to $\mu$ phenolic/ $g$ dry weight. Sixteen standard phenolic compounds were obtained from Sigma (St. Louis, USA) and from Merck-Schuchardt (Munich, Germany) Chemical Companies.

Measurement of sunflower oil stability:

The extracted total polyphenols from virgin, curde pomace olive oils and vegetation water of ripe Kronaki fruits were added to sunflower oil at levels; $0.01,0.03,0.05,0.10$ and $0.15 \%$. The oxidative and thermal stability of sunflower oil was measured by Rancimat.

Oxidative stability was evaluated according to Gutièrrez (1989) by using 679 Rancimat (Metrohm Ltd., CH.9100 Herisau, Switzerland) at Agric. Res., Center, Giza, Egypt. five grams of sunflower oil as well as treated sunflower oil by phenolic extracts were exposed to a stream of atmospheric oxygen $(20 \mathrm{~L} / \mathrm{h})$ at $100 \pm 2^{\circ} \mathrm{C}$. The volatile decomposition products (mainly organic acids) are trapped a measuring detected with distilled water $(60 \mathrm{ml})$ and continuously detected with a conductivity cell (conductivity range 25-200 us $/ \mathrm{cm})$.

Statistical analysis: Data were subject to statistical analysis using "F" test according to Snedecor and Cochran (1973) and L.S.D. value for comparisons according to Gomez and Gomez (1984).

\section{RSEULTS AND DISCUSSION}

Total polyphenols: Total polyphenols of virgin, crude pomace olive oils and vegetation water of the studied olive varieties were presented in Table (1). Data revealed that there were considerable differences in total polyphenols content between virgin, crude pomace olive oils and vegetation water of all studied varieties. Also, it was clear that total polyphenols content of virgin, crude pomace olive oils and vegetation water significantly increased from unripe to the ripe stage in all varieties. These results are in agreement with those reported by Salvador et al. (2001) and Rovellini and Cortesi (2003), they recorded that the content of total polyphenols was increased in olive oils from unripe to ripe stage. While, Gimeno et al. (2002) showed that phenols were decreased during ripening. On the other hand, Kronaki fruits recorded the highest total polyphenols content followed by Frantoio, Mission and Chemlali in both two ripening stages. Total polyphenols content was 315 and $335 \mathrm{ppm}$ (virgin oil), 68 and $75 \mathrm{ppm}$ (crude pomace oil) and 230 and $250 \mathrm{ppm}$ (vegetation water) in Kronaki fruits at unripe and ripe stage, respectively. Moreover, the data also indicated that the vegetation water contained considerable amounts of polyphenols in some varieties. The differences in the total phenolic content could be related to the agronomic 
characteristics of olive fruits considering the time of their respective ripening (Morelló et al., 2005). Besides, the phenolic compound content in oil depends on the place of cultivation, the climate, the variety and the olive's level of maturation at the time of harvesting (Cinquanata et al., 1997 and Visioli and Galli, 1998).

Concerning statistical analysis, it could be noticed that there were no significant differences in all treatments but, there were significant differences in case of variety in vegetation water and in case of interaction between variety and ripening in Virgin olive oil at LSD 5\%.

Phenolic compounds composition: Data of polyphenol compounds of the studied virgin olive oils at ripe stage by HPLC apparatus are shown in Table (2). There were twelve identified phenolic compounds and seven unknown fractions. From these results it could be concluded that $p$-coumaric acid was the major polyphenols compound represented 13.40, 11.53, 9.50 and 7.70 $\%$ followed by o-coumaric acid which recorded $6.54,7.37,8.78$ and $5.98 \%$ of total polyphenols in Kronaki, Mission, Frantoio and Chemlali, respectively. On the other hand, gallic, catechin, $p$-hydroxybenzoic, salicylic, quercetin, cinnamic acids and phenol present as minor compounds in all studied olive oils with the exception of gallic acid it not found in Mission variety. The concentration of salicylic, catechin, cinnamic acids and phenol in all virgin olive oils varied from 2.99 to $3.56 \%, 2.50$ to $3.45 \%, 1.82$ to $3.75 \%$ and 1.50 to $2.76 \%$ of total polyphenol, respectively.

Table (1): Total polyphenols content of virgin, crude pomace olive oils and vegetation water (ppm):

\begin{tabular}{|c|c|c|c|c|c|c|c|c|c|}
\hline \multirow[t]{2}{*}{\begin{tabular}{|l|} 
Property \\
Variety
\end{tabular}} & \multicolumn{3}{|c|}{$\begin{array}{l}\text { Virgin } \\
\text { olive oil }\end{array}$} & \multicolumn{3}{|c|}{$\begin{array}{c}\text { Crude pomace olive } \\
\text { oil }\end{array}$} & \multicolumn{3}{|c|}{$\begin{array}{l}\text { Vegetation } \\
\text { water }\end{array}$} \\
\hline & Unripe & Ripe & Mean & Unripe & Ripe & Mean & Unripe & Ripe & Mean \\
\hline Chemlali & 120 & 130 & 125 & 50 & 63 & 57 & 125 & 136 & 131 \\
\hline Kronaki & 315 & 335 & 325 & 68 & 75 & 72 & 230 & 250 & 240 \\
\hline Frantoio & 160 & 170 & 165 & 60 & 70 & 65 & 150 & 240 & 195 \\
\hline Mission & 128 & 161 & 146 & 45 & 52 & 49 & 155 & 165 & 160 \\
\hline Mean & 181 & 199 & - & 56 & 65 & - & 165 & 198 & - \\
\hline \multicolumn{10}{|l|}{ L.S.D. 0.05\% } \\
\hline Variety (V) & \multicolumn{3}{|c|}{3} & \multicolumn{3}{|c|}{3} & \multicolumn{3}{|c|}{6} \\
\hline Ripening (R) & \multirow{2}{*}{\multicolumn{3}{|c|}{4}} & \multirow{2}{*}{\multicolumn{3}{|c|}{$\begin{array}{l}2 \\
1\end{array}$}} & \multirow{2}{*}{\multicolumn{3}{|c|}{$\begin{array}{l}3 \\
4\end{array}$}} \\
\hline$V \times R$ & \multicolumn{2}{|r|}{6} & & & & & & & \\
\hline
\end{tabular}

It was evident from the same data (Table, 2) that the polyphenols; pyrogallic, protocatchuic and coumaric acids recorded the lowest levels. Pyrogallic acid constituted only $0.02,0.35,0.20$ and $0.30 \%$ of total polyphenols for Chemlali, Kronaki, Frantoio and Mission virgin olive oils, respectively. Protocatchuic and coumaric acid percentages ranged from 0.14 and $0.66 \%$ for Chemlali to 0.85 and $0.92 \%$ for Kronaki, respectively. The relative proportion of phenolic components depends on several factors such as fruit's variety, location, and degree of ripeness (Caponio et al., 2001 and Cinquanata et al., 1997). Moreoever, polyphenols are present as phenolic acids (caffeic, $p$-coumaric, ferrulic, $p$-hydroxybenzoic and vanillic acids) as well as phenolic alcohols (tyrosol and hydroxytyrosol) in olive oil Koprivnjak and Conte (1998). 
Khalifa, A.H.A. et al.

Table (2): Phenolic compounds composition (\% of total polyphenols):

\begin{tabular}{|l|c|c|c|c|}
\hline \multirow{2}{*}{} & \multicolumn{4}{|c|}{ Virgin olive oils } \\
\cline { 2 - 5 } & Chemlali & Kronaki & Frantoio & Mission \\
\hline Unknown 1 & 0.06 & 0.72 & ND $^{*}$ & 0.09 \\
\hline Unknown 2 & 0.75 & 0.34 & 0.92 & 0.82 \\
\hline Unknown 3 & 0.19 & 0.53 & 0.45 & 0.20 \\
\hline Pyrogallic & 0.02 & 0.35 & 0.20 & 0.30 \\
\hline Gallic acid & 1.98 & 2.03 & 3.52 & ND \\
\hline Protocatchuic acid & 0.14 & 0.85 & 0.34 & 0.19 \\
\hline Catechin & 2.61 & 3.45 & 3.20 & 2.50 \\
\hline$P$-hydroxybenzoic & 2.31 & 0.70 & 1.45 & 1.70 \\
\hline Unknown 4 & 1.42 & 1.02 & 1.95 & 1.85 \\
\hline$P$-Coumaric & 7.70 & 13.40 & 9.50 & 11.53 \\
\hline Unknown 5 & 2.23 & $\mathrm{ND}$ & 3.57 & 2.56 \\
\hline Phenol & 2.76 & 1.75 & 1.50 & 2.32 \\
\hline O-Coumaric & 5.98 & 6.54 & 8.78 & 7.37 \\
\hline Salicylic acid & 2.99 & 3.56 & 3.19 & 3.00 \\
\hline Coumaric acid & 0.66 & 0.92 & 0.83 & 0.78 \\
\hline Quercetin & 1.53 & 1.02 & 1.32 & 1.28 \\
\hline Unknown 6 & 0.42 & 0.30 & 1.00 & 0.59 \\
\hline Cinnamic acid & 1.82 & 3.57 & 2.18 & 3.04 \\
\hline Unknown 7 & 66.60 & 58.97 & 56.10 & 62.92 \\
\hline
\end{tabular}

$\mathrm{ND}^{*}=$ not detected.

Physico-chemical properties and stability of sunflower oil: The refractive index, acid value, peroxide value and iodine value were determined for the used sunflower oil and the results are shown in Table (3). From these data, it is clear that no hydrolytic and oxidative rancidity has taken place for sunflower oil. Besides, the oxidative stability for sunflower oil was $9.41 \mathrm{~h}$, which be considered initial value before the addition olive's polyphenol extracts to evaluate then effect on the stability of this oil.

Table (3): Physico-chemical indices and stability of sunflower oil:

\begin{tabular}{|l|c|}
\hline \multicolumn{1}{|c|}{ Indices } & Value \\
\hline Refractive index $\left(25^{\circ} \mathrm{C}\right)$ & 1.4643 \\
\hline Acidity $(\%)$ as oleic acid & 0.01 \\
\hline Peroxide value $(\mathrm{meq} / \mathrm{kg})$ & 0.01 \\
\hline lodine value $(\mathrm{g} / 100 \mathrm{~g})$ & 134.78 \\
\hline Oxidative stability $(\mathrm{hr})$ & 9.41 \\
\hline
\end{tabular}

Effect of olive's total polyphenols addition on sunflower oil stability:

Total polyphenols was extracted from virgin, crude pomace oils and vegetation water of ripe Kronaki olive variety because it has the highest amount of polyphenols among the studied olive varieties. Polyphenols extracts were added at levels of $0.01,0.03,0.05,0.10$ and $0.15 \%$ to sunflower oil (w/v)and the data of oxidative stability were tabulated in Table 4. Generally, the results revealed that the addition of olive's polyphenols extracts increased the stability of treated sunflower oil compared to the 
control. Moreover, increasing the concentration of polyphenols extracts from 0.01 to $0.15 \%$ remarkable exhibited the antioxidant activity of sunflower oil. The stability of sunflower oil was nearly duplicated at $0.15 \%$ extract addition compared with the control. The data are in the line with those reported by Farag et al. (2003 and 2004).

Table (4): Oxidative stability of sunflower oil as affected by Kronaki polyphenol extracts addition:

\begin{tabular}{|c|c|c|c|c|c|c|}
\hline \multirow{2}{*}{ Polyphenols } & \multicolumn{2}{|c|}{ Virgin oil } & \multicolumn{2}{c|}{ Crude pomace oil } & \multicolumn{2}{|c|}{ Vegetation water } \\
\cline { 2 - 7 } & $\begin{array}{c}\text { Stability } \\
\text { (hr) }\end{array}$ & $\begin{array}{c}\text { Protective } \\
\text { factor }\end{array}$ & $\begin{array}{c}\text { Stability } \\
\text { (hr) }\end{array}$ & $\begin{array}{c}\text { Protective } \\
\text { factor }\end{array}$ & $\begin{array}{c}\text { Stability } \\
\text { (hr) }\end{array}$ & $\begin{array}{c}\text { Protective } \\
\text { factor }\end{array}$ \\
\hline Control & 9.41 & 1.00 & 9.41 & 1.00 & 9.41 & 1.00 \\
\hline 0.01 & 12.80 & 1.36 & 15.00 & 1.59 & 12.90 & 1.37 \\
\hline 0.03 & 14.50 & 1.54 & 15.40 & 1.63 & 16.00 & 1.70 \\
\hline 0.05 & 15.20 & 1.61 & 15.60 & 1.65 & 16.90 & 1.79 \\
\hline 0.10 & 15.80 & 1.67 & 16.30 & 1.73 & 19.40 & 2.06 \\
\hline 0.15 & 17.20 & 1.82 & 16.60 & 1.76 & 21.50 & 2.28 \\
\hline
\end{tabular}

On the other hand, it was clear that the polyphenols extract from vegetation water was more effective on sunflower oil stability compared to that of virgin or crude pomace extracts. The high protective effect of vegetation water polyphenols extract may be due to present of some polyphenols compounds have water solubility. Such results are in accordance with those reported by Khalil (1994) and Ismeal et al. (1996).

In conclusion polyphenols extracts of olive oil can be used as natural antioxidants for increasing stability of other oils as well as the importance of using the vegetation water (a by product of olive oil industry) as natural antioxidant source.

\section{REFERENCES}

Aguilera, M.P.; Beltrán, G.; Ortega, D.; Fernádez, A.; Jiménez, A. and Uceda, M. (2005). Characterization of virgin olive oil of Italian olive cultivars; Frantoio and Leccino grown in Andalusia Food Chem., 89:387-391.

Akasbi, M.; Shoeman, D.W. and Csallany, A.S. (1993). High performance liquid chromatography of selected phenolic compounds in olive oils. J. Am. Oil Chem. Soc., 70 (4):367-370.

AOAC (2000). Official Methods of Analysis of Association of Official Agriculture Chemists. International $17^{\text {th }}$ edition. W. Horwtiz, Washington D. C.

Boskou, D. (1996). Olive oil: Chemistry and technology. AOAC Press, Champing, pp. 85-127.

Capasso, R.; Cristinzio, G.; Evidente, A. and Scognamiglio, F. (1992). Isolation, spectroscopy and selective phytotoxic effects of polyphenols from vegetable waste waters. Photochemistry, 31 (12):4125-4128.

Caponio, F.; Gomes, T. and Pasqualone, A. (2001). Phenolic compounds in virgin olive oils: influence of the degree of olive ripeness on organoleptic characteristic and shelf-life. Euro. Food Res. Tech., 212:329-333. 
Caruso, D.; Berra, F.; Giavarini, F.; Cortesi, N.; Fedeli, E. and Galli, G. (1999). Effect of virgin olive oil phenolic compounds on in vitro oxidation of human low density lipoproteins. Nutr. Metab. Cardiovasc. Dis., 9:102107.

Chimi, H. and Atouati, Y. (1994). Determination of the optimal stage for harvesting Moroccan, Picholine olives by monitoring change in total polyphenols. Olivea, 54:56-60.

Cinquanata, L.; Esti, M. and Notte, E. (1997). Evaluation of phenolic compounds in virgin olive oil during storage. J. Am. Oil. Chem. Soc., 74(10): 1259-1264.

Duch, P.D.; Yeh, D.B. and Yen, G.C. (1992). Extraction and identification of an antioxidative component from peanut hulls. J. Am. Oil Chem. Soc., 69:814-818.

Farag, R.S.; El-Baroty, G. and Basuny, A.A. (2003). The influence of phenolic extracts obtained from the olive plant (cvs. Picual and Kronaki) on the stability of sunflower oil. Inter. J. Food Sci. Tech., 38:81-87.

Farag, R.S.; El-Baroty, G. and Basuny, A.A. (2004). Use of crude olive leaves juice as natural antioxidant for the stability of heated sunflower oil. Egypt. J. Agric. Res., 82(3):217-236.

Fayed, Z.; Shrabar, E. and Neeman, I. (1988). Separation and concentration of natural antioxidants from the rape of olives. J. Am. Oil Chem. Soc., 65 (6): 990-993.

Firestone, D.; Carsone, K.L. and Reina, R.J. (1988). Update on control of olive adulteration and misbranding in the United States. J. Am. Oil Chem. Soc., 65:788-792.

Frankel, E.N.; Waterhouse, A.L. and Teissedre, P. (1995). Principal phenolic phytochemicals in selected California wines and their antioxidant activity in inhibiting oxidation of human low density lipoproteins. J. Agric. Food Chem., 43: 890- 894.

Gazzani, G.; Papetti, A.; Massolini, G. and Daglia, M. (1998). Antioxidative and pro-oxidant activity of water soluble components of some common diet vegetables and the effect of thermal treatment. J. Food Chem., 6: 4118-4122.

Gennaro, L.; Piccioli Bocca, A.; Masella, R. and Coni, E. (1998). Effect of biophenols on olive oil stability evaluated by thermogravimetric analysis. J. Agric. Food. Chem., 46 (11):4465-4469.

Gimeno, E.; Castellote, A. I.; Lamual-Raventoś, R.M.; Torre, D. and LópezSabater, M.C. (2002). The effect of harvest and extraction methods on the antioxidant content (phenolic, $\alpha$-tocopherol and $\beta$-carotene) in virgin olive oil. Food Chem., 78 (2):207-211.

Gomez, K.A. and Gomez, A.A. (1984). Statistical Procedures for Agricultural Research $2^{\text {nd }}$ John Wily, NY., pp. 680.

Gutiérrez -Rosales, F. G.; Perediguero, S.; Gutiérrez, R. and Olias, J. (1992). Evaluation of bitter taste in virgin olive oil. J. Am. Oil Chem. Soc., 69: 394-395.

Gutiérrez, F. (1989). Determination of oxidative stability in virgin olive oils: composition between active oxygen method and Rancimat method. Grasasy Aceities 40:1-5. 
Gutifinger, T. (1981). Polyphenol in olive oils. J .Am. Oil Chem. Soc., 9: 966968.

Ismael, A.I.; Khalil, M.F. and Badawy, H.A.A. (1996). Effect of natural and synthetic antioxidants on the stability virgin olive oil. Annals. Agric. Sci. Ain Shams Univ., Cairo, 41(1): 269-280.

Khalil, M.F (1994). Polyphenol content and stability of virgin olive oils, separation of natural antioxidant from vegetation water of olives. Egypt. J. Agric. Res., 72(2): 577-588.

Koprivnjak, O. and Conte, L. (1998). Specific components of virgin olive oil as active participants in oxidative process. Food Tech. Bio., 36: 223 - 224.

Liu, R.H. (2000). Cancer-An apple a day helps keep cancer away. Nature, 405: 903- 904.

Montedoro, G.; Servili, M.; Baldiol, M. and Miniati, E. (1992). Simple and hydroxyzable phenolic compounds in virgin olive oil 1. Their extraction, separation and quantitive and semiquantitive evaluation by HPLC. J. Agric. Food Chem., 40:1571-1576.

Morelló, J.; Romero, M.; Ramo, T. and Motilva, M. (2005). Evaluation of Lphenylalanine ammonia-lyase activity and phenolic profile in olive drupe (Olea europaea $L$.) from fruit setting period to harvesting time. Plant Sci., 168 (1):65-72.

Papadopoulos, G. and Boskou, D. (1991). Antioxidants effect of natural phenols on olive oil. J. Am. Oil Chem. Soc., 68 (9): 669-671.

Rice-Evans, C.A.; Miller, N.T. and Paganga, G. (1997). Antioxidant properties of phenolic compounds. Trends in Plant Sci. 4: 304-309.

Rovellini, P. and Cortesi, N. (2003). Determination of phenolic compounds in different cultivars during olive drupe ripening by liquid chromatographymass spectrometry. Olivae, 95(2): $32-38$.

Salah, N.; Miller, N.J.; Paganga, G.; Tijburg, L.; Bolwell, P. and Rice-Evans, C. (1995). Polyphenolic flavonoids as scavengers of aqueous phase radicals and as chain breaking antioxidant. Archives in Biochm. And Biophysics, 322: 339-346.

Salvador, M.D.; Aranda, F. and Fergapane, G. (2001). Influence of fruit ripening on "Cornicabra" virgin oil quality. A study of four successive crops seasonal. Food Chem., 73 (1):45-43.

Satue, M.T.; Huang, S.H. and Frankel, E.N. (1995). Effect of natural antioxidants in virgin olive oil on oxidative stability of refined, bleached and deodorized olive oil. J. Am. Oil Chem. Soc., 72:1323-1327.

Snedecor, G.W. and Cochran, W.G. (1973). Statistical methods. Sixth edition, lowa State Univ. Press., lowa. U.S.A.

Visioli, F. and Galli, C. (1998). The effect of minor constituents of olive oil on cardiovascular disease: new finding. Nutr. Rev., 56:142-147.

Yen, G.C.; Chen, H.W. and Duh, P.D. (1998). Extraction and identification of an antioxidative component from Jue Ming Zi (Cassia tora L.). J. Food Chem., 46: 820- 824. 
Khalifa, A.H.A. et al.

تقييم واستخدام المواد الفينولية لمستخلصات الزيتون كمضادات أكسدة طبيعية

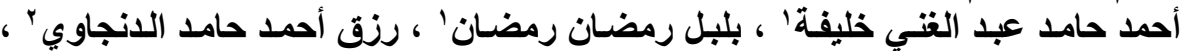

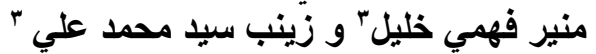

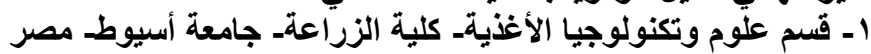

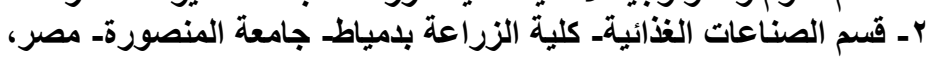

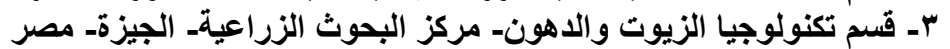

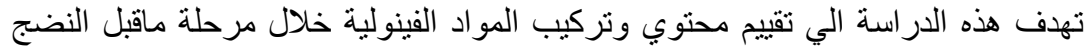

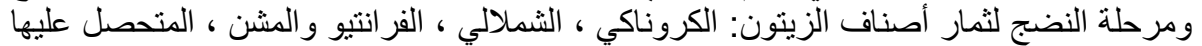

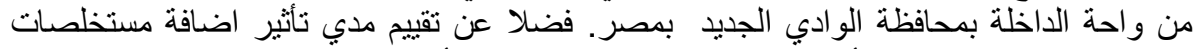

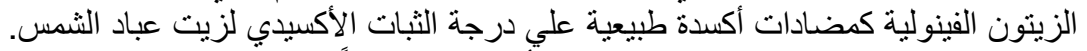

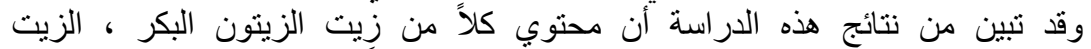

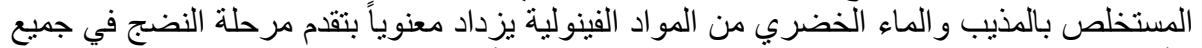

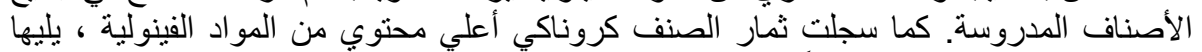

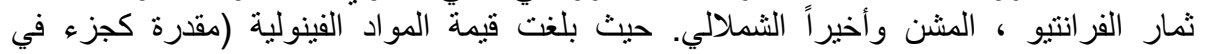

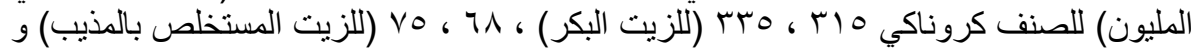

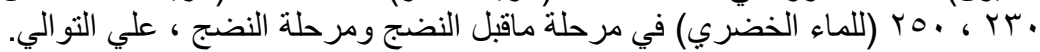

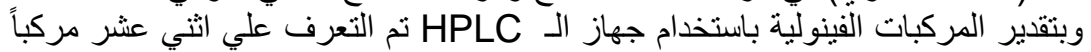

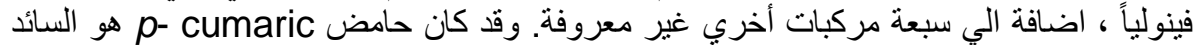

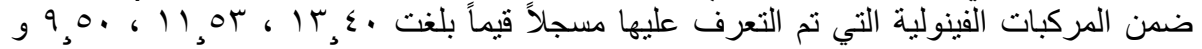

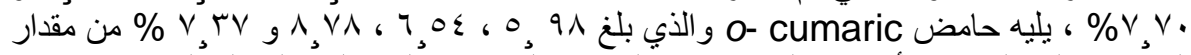

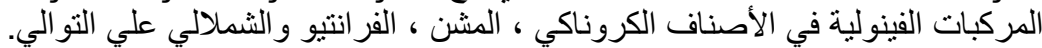

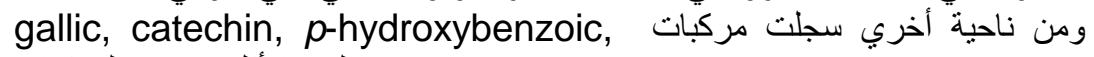
salicylic, quercetin, cinnamic acids and phenol الفينولية المنعرف عليها في جميع أصناف الزيتون الددروسة.

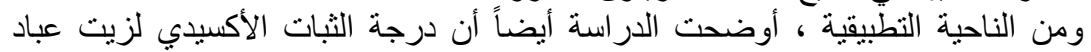

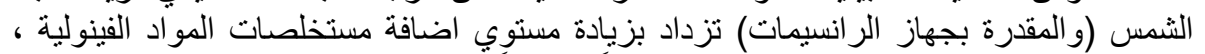

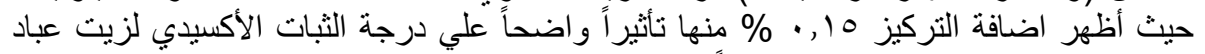

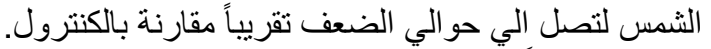

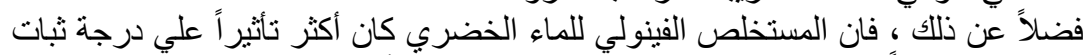

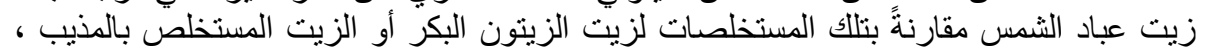

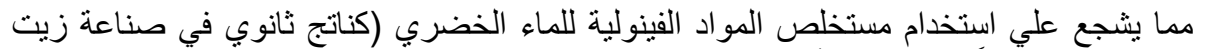
الزيتون) كمصدراً لمضادات الأكسدة الطبيعية. 